\title{
Insecticidal activity of Laureliopsis philippiana (Looser) Schodde (Atherospermataceae) essential oil against Sitophilus spp. (Coleoptera Curculionidae)
}

\author{
Carolina Norambuena ${ }^{1}$, Gonzalo Silva ${ }^{1 *}$, Angēlica Urbina ${ }^{1}$, Inés Figueroa ${ }^{1}$,
} and J. Concepciōn Rodríguez-Maciel ${ }^{2}$

\section{ABSTRACT}

In Chile, the main Coleopteran species of stored grains are Sitophilus oryzae, S. zeamais, and S. granarius. The aim of this study was to evaluate under laboratory conditions the contact and fumigant insecticidal activity, as well as the repellent and antifeedant effects of Laureliopsis philippiana (Looser) Schodde essential oil against adults of Sitophilus spp. The main compounds identified in this essential oil were methyleugenol $(61.38 \%)$ and safrole $(14.76 \%)$. Based on the contact bioassay, the highest toxicity was achieved with the concentration of $4.0 \%(\mathrm{v} / \mathrm{w})$, and $S$. oryzae was the most susceptible species. Emergence $\left(F_{1}\right)$ was reduced as the concentration of the essential oil increased, reaching maximums of $60 \%$ in the case of $S$. granarius and S. oryzae, and $36 \%$ in S. zeamais. Mortality by fumigant activity was $100 \%$ for the three species of Sitophilus. All of the treatments had a repellent effect. The highest antifeedant activity (82.9\%) was recorded at $4.0 \%$ (v/w) concentration. Concentrations below $2.0 \%(\mathrm{v} / \mathrm{w}) \mathrm{did}$ not affect germination of maize. Based on these results, L. philippiana essential oil has the potential to control Sitophilus spp. weevils.

Key words: Botanical insecticide, contact toxicity, fumigant effect, stored grains, Tepa, weevil.

${ }^{1}$ Universidad de Concepción, Facultad de Agronomía, Vicente Méndez 595, Chillán, Chile. "Corresponding author (gosilva@udec.cl).

${ }^{2}$ Colegio de Postgraduados Campus Montecillo, km 38.5 Carr. México-Texcoco, Montecillo, Estado de México, México.

Received: 25 January 2016

Accepted: 5 May 2016.

doi:10.4067/S0718-58392016000300010

\section{INTRODUCTION}

Cereals are an essential part of the human and animal diet. Unfortunately, insects may destroy up to $50 \%$ of harvested grains (De Lira et al., 2015). There are three important pest species of stored grain, and all of them belong to the genus Sitophilus spp. (Coleoptera: Curculionidae): S. oryzae, S. granarius, and $S$. zeamais. In addition to the physical damage that they cause to the grain, these species of insects also allow the entry of pathogenic organisms, such as fungi or bacteria (Bakkali et al., 2008). Tefera et al. (2011) have indicated that about $10 \%$ of the grains may be infested at harvest time, but as infestation continues during the storage, loss reach $30 \%$ to $50 \%$ in 6-mo. Therefore, protection techniques are required.

Aluminum phosphide is the most widely used fumigant pesticide because of its efficacy and low cost. However, synthetic fumigants have caused in recent decades alteration of biological balance and insecticide resistance (Chu et al., 2010). These problems have highlighted the need to look for new chemicals to use as control agents, including plant extracts. These compounds are providing new modes of action against insects, are friendlier to the environment, and also reduce the risk of insecticide-resistance (Isman, 2006; 2008).

Some plant insecticides are essential oils and contain complex mixtures of 20 to 60 compounds. Two or three of these components are usually at high concentrations (20\% to $70 \%$ ) compared to others that occur in trace amounts (Pérez et al., 2010). They are secondary metabolites, some of which have contact and fumigant insecticidal activity, as well as ovicidal, antifeedant and repellent effects (Bakkali et al., 2008). Isman (2006) has indicated that essential oils and their components can be potential insect-control alternatives with important advantages, such as being readily available in the agroecosystem, degrading quickly and providing lower toxicity to mammals.

Bittner et al. (2009) found that essential oils from three Chilean native species: Boldo (Peumus boldus Molina), tepa (Laureliopsis philippiana (Looser) Schodde) and laurel (Laurelia sempervirens (Ruiz \& Pav.) Tul.) (Atherospermataceae family), have secondary metabolites in common. These three species contain terpenes 3 -carene, $\alpha$-pinene and $\alpha$-phellandrene, while tepa and laurel contain safrole. The essential oils of L. sempervirens and P. boldus are promising for pest control of stored grains, such as the red flour beetle Tribolium castaneum (Herbst.) and the greater grain weevil S. zeamais (Zapata and Smagghe, 2010; Betancur et al., 2010). If these three tree species have some compounds in common, 
the essential oil of L. philippiana could have similar biological activity. Therefore, the objective of this study was to evaluate, under laboratory conditions, the contact and fumigant insecticidal activity, as well as the repellent and antifeedant effects of essential oil of L.philippiana on adults of S. zeamais, S. oryzae, and S. granarius.

\section{MATERIALS AND METHODS}

\section{Essential oil and insects}

The essential oil was extracted from leaves of L. philippiana collected in Maullin (4041' S, $73^{\circ} 25^{\prime}$ W; $28 \mathrm{~m}$ a.s.1.), Los Lagos Region, Chile. Leaves were randomly selected from the four cardinal points of the central part of the trees. Once collected they were taken to the Laboratory of Entomology, College of Agriculture, University of Concepción, Chillán, and oven dried (Memmert GmbH, UNB 500, Schwabach, Germany) at $40 \pm 1{ }^{\circ} \mathrm{C}$, and then ground in an electric coffee grinder (Sindelen, MOL-165, NOX, China). The essential oil was extracted from $500 \mathrm{~g}$ ground leaves in $1000 \mathrm{~mL}$ distilled water by steam distillation with a Clevenger-type equipment for $2 \mathrm{~h}$. The identification of collected foliage was verified by comparison with reference voucher CONC$\mathrm{CH} 237$ deposited in the herbarium of College of Agriculture, University of Concepción, Chillán. The chemical analysis of essential oil was performed by gas chromatography (GC) coupled to mass spectrometry detection (GC-MS), using a high performance gas chromatography mass spectrometry (HPGC-MS series II 5890; Hewlett Packard, Palo Alto, California, USA) at the Laboratory of Pharmacognosy, Faculty of Pharmacy, University of Concepción.

Three species of Sitophilus were evaluated: $S$. granarius, S. oryzae and S. zeamais. Insects were obtained from colonies permanently maintained in the Laboratory of Entomology. They were reproduced at $25 \pm 2{ }^{\circ} \mathrm{C}, 60 \% \mathrm{RH}$ and total darkness within a bioclimatic chamber (IPS 749, Memmert Gmbh), using maize (Zea mays L.) as a food source. Maize grains were obtained from the Fruit, Grains and Vegetable Market of Chillán. Kernels were washed with potable water to prevent external contamination by insects and to remove insecticide residues, and then stored at $4.5 \pm 1{ }^{\circ} \mathrm{C}$ until use.

\section{Contact and fumigant toxicity}

The bioassay was conducted using the methodology described by Betancur et al. (2010). Each experimental unit consisted of $200 \mathrm{~g}$ maize kernels placed in 400-mL glass flasks, adding essential oil mixed with $1 \mathrm{~mL}$ acetone at $0.25 \%, 0.5 \%, 1.0 \%$, $2.0 \%$, and $4.0 \% \mathrm{v} / \mathrm{v}$, plus a control with only $1 \mathrm{~mL}$ acetone. Each flask was shaken during $15 \mathrm{~s}$ so that all kernels were evenly covered with the solution, and left for $2 \mathrm{~h}$ at room temperature to allow for acetone evaporation. Then, each flask was infested with 10 couples of 1-wk-old insects, sexed according to Halstead (1963). Each treatment had four replicates. Flasks were stored in a bioclimatic chamber at 25 $\pm 2{ }^{\circ} \mathrm{C}, 60 \% \mathrm{RH}$ and full darkness. Mortality was assessed $15 \mathrm{~d}$ after infestation (DAI) and data were corrected by means of Abbott's formula (Abbott, 1925). Once mortality was recorded, all adult insects were removed; the flasks were put back in the bioclimatic chamber for $40 \mathrm{~d}$ (55 DAI) to evaluate adult emergence $\left(\mathrm{F}_{1}\right)$. The insect emergence in the control was considered $100 \%$.

Residual activity was assessed only for concentrations that caused at least $60 \%$ mortality in the contact toxicity bioassay. The procedure to mix the grains with the essential oils was the same described above. The flasks containing the treated grains were stored without insects in a bioclimatic chamber during 1,5 , and $10 \mathrm{~d}$, at the indicated conditions. After that, the flasks were infested with 20 adult insects and returned to bioclimatic chamber. Mortality was assessed at 24,48 , and $72 \mathrm{~h}$ from insect infestation and mortality was corrected with Abbott's formula (Abbott, 1925).

The fumigant activity was conducted using the methodology described by Brito et al. (2006), which consisted of applying undiluted essential oil on a circular sheet of filter paper of $6.5 \mathrm{~cm}$ in diameter, which was attached to the inside of the lid of a $150-\mathrm{mL}$ plastic container. This contained $20 \mathrm{~g}$ of infested maize with 10 adult unsexed insects. The essential oil concentrations evaluated were 35, 70, 100, 140, 170,200 , and $240 \mu \mathrm{L}$ essential oil $\mathrm{L}^{-1}$ air, plus an untreated control consisting of filter paper only. Each treatment had four replicates, which were stored in a bioclimatic chamber at $25 \pm 2{ }^{\circ} \mathrm{C}$ and $60 \%$ RH. Mortality was assessed 5 DAI and data were corrected with Abbott's formula.

\section{Repellent and antifeedant effects}

Repellency was evaluated using the methodology of Pérez et al. (2012), so that, a device known as choice arena was used, consisting of five plastic Petri dishes ( $5 \mathrm{~cm}$ diameter): the central one connected to the other four through plastic tubes in an X-shape arrangement. The treatments evaluated were $0.25 \%, 0.5 \%, 1.0 \%, 2.0 \%$, and $4.0 \%(\mathrm{v} / \mathrm{v})$ of essential oil diluted in $1 \mathrm{~mL}$ acetone. Two opposite dishes containing $20 \mathrm{~g}$ maize kernels mixed with a treatment, while the other two dishes contained the untreated control treatment, which consisted of $20 \mathrm{~g}$ kernels mixed with acetone. Then, 20 adult insects (48 h-old) were released in the central dish, and then, the number of insects per dish was recorded after 24 $\mathrm{h}$. The repellency index (RI) was calculated according to the methodology proposed by Restello et al. (2009), in which the oil is classified as neutral if $\mathrm{RI}=1$, attracting if $\mathrm{RI}>1$ and repellent if $<1$.

The antifeedant effect bioassay was conducted using the methodology described by Napoleao et al. (2013), with some modifications. Wheat flour discs were prepared by mixing 100 $\mathrm{mL}$ distilled water with $40 \mathrm{~g}$ flour. Then, $1 \mathrm{~mL}$ of the solution was placed on a silicone sheet by using a micropipette and allowed it to dry $24 \mathrm{~h}$ at room temperature. Once dried, each disk was impregnated with $0.5 \mu \mathrm{L}$ of essential oil solution at $0 \%, 0.25 \%, 0.5 \%, 1.0 \%, 2.0 \%$, and $4.0 \%(\mathrm{v} / \mathrm{v})$ diluted in 1 $\mathrm{mL}$ acetone. The initial weight of each disc was determined and then the discs were placed in a plastic Petri dish of $5 \mathrm{~cm}$ in diameter infested with five adult insects. The weight of the flour discs was determined $3 \mathrm{DAI}$ and measurements were 
adjusted subtracting moisture loss. The antifeedant activity was determined by means of the Farrar formula (Haouas et al., 2010). Each treatment had four replicates and two controls were included, one consisting of a flour disc treated with acetone and the other with untreated flour (untreated control), in order to estimate moisture loss.

\section{Germination and plant development}

In these variables, two bioassays were carried out. In first experiment, for each replicate, 20 maize kernels randomly selected were allowed to germinate at room temperature (20 $\pm 2{ }^{\circ} \mathrm{C}$ ). Kernels were previously impregnated with essential oil dissolved in $1 \mathrm{~mL}$ acetone at concentrations of $0.25 \%$, $0.5 \%, 1.0 \%, 2.0 \%$, and $4.0 \%(\mathrm{v} / \mathrm{v})$. A control treatment was included, consisting of $1 \mathrm{~mL}$ acetone placed in glass Petri dishes with a moisted filter paper on the base. Germination was evaluated on a daily basis and each treatment had four replicates. The number of germinated kernels in the control was considered as $100 \%$. The other bioassay consisted in immersing 20 maize seeds in a solution of essential oil dissolved in $1 \mathrm{~mL}$ acetone at the concentrations indicated above. The impregnated seeds were planted in $3 \mathrm{~L}$ pots containing a mixture of peat moss (Kekkila 025 Natural W; Protekta, Santiago, Chile) and perlite (Perlite A13; Protekta) in a 3:1 proportion and located in the glasshouses during $25 \mathrm{~d}$. After this period emerged plants were harvested, then plant height, DM weight and root length were assessed.

In all bioassays a completely randomized experimental design was used. Data obtained in each bioassay were tested for normality using a modified Shapiro-Wilks test and the homogeneity of variances was tested by means of the Levene's test. An arcsine transformation (180 (arc $\sqrt{ }((\mathrm{x}) / 100)) / \mathrm{Pi})$ was used with all data that did not meet the assumptions. Once normalized, data were submitted to ANOVA and Tukey's test (means comparison) with a 5\% significance level. In the residual bioassay, non-parametric Kruskal Wallis test was used. InfoStat software (Facultad de Ciencias Agropecuarias, Universidad Nacional de Córdoba, Córdoba, Argentina) was used in all analyzes.

\section{RESULTS AND DISCUSSION}

\section{Phyto-chemical characterization of the essential oil}

The main components of tepa essential oil identified in this study were phenylpropane compounds $(78.42 \%)$, and the most abundant ones were methyleugenol $(61.38 \%)$ and safrole $(17.04 \%)$ (Table 1). These results are different from those documented by Bittner et al. (2009), who indicated that the main compounds were 1,8-cineole (14.76\%) and 3 -carene $(53.81 \%)$, which were not detected in our study. These authors did not find methyleugenol, but indicated the presence of safrole at low levels (2.33\%). Similarly, Niemeyer and Teillier (2007) and Toledo et al. (2014) identified 1,8-cineole as one of the most abundant compounds in the essential oil of L. philippiana.
Table 1. Phytochemical characterization of Laureliopsis philippiana essential oil.

\begin{tabular}{|c|c|c|c|}
\hline Time (min) & Compound & $(\%)$ & Identification* \\
\hline 5.31 & $\beta$-Terpinene & 4.49 & IK, MS \\
\hline 5.94 & Unknown & 0.29 & IK, MS \\
\hline 6.00 & Unknown & 0.46 & IK, MS \\
\hline 6.17 & Sabidene & 0.28 & IK, MS \\
\hline 6.43 & $\alpha$-Phellandrene & 1.08 & IK, MS \\
\hline 6.77 & Q-Cymene & 0.77 & IK, MS \\
\hline 6.85 & Unknown & 4.82 & IK, MS \\
\hline 7.10 & Ocimene & 1.77 & IK, MS \\
\hline 7.79 & Isoterpinolene & 0.12 & IK, MS \\
\hline 7.93 & Linalool & 0.85 & IK, MS \\
\hline 9.04 & Borneol & 0.11 & $\mathrm{IK}, \mathrm{MS}$ \\
\hline 9.21 & (-)-Terpinen-ol & 0.13 & IK, MS \\
\hline 9.36 & Unknown & 0.19 & $\mathrm{IK}, \mathrm{MS}$ \\
\hline 9.39 & Terpineol & 0.44 & IK, MS \\
\hline 9.49 & 2-Allyl-4-methylphenol & 0.74 & $\mathrm{IK}, \mathrm{MS}$ \\
\hline 10.86 & Safrole & 17.04 & IK, MS, S \\
\hline 12.42 & Methyleugenol & 61.38 & IK, MS, S \\
\hline 12.70 & Caryophilene & 0.35 & $\mathrm{IK}, \mathrm{MS}$ \\
\hline 13.14 & Unknown & 0.09 & IK, MS \\
\hline 13.23 & (-)-Alloaromadendrene & 0.37 & IK, MS \\
\hline 13.47 & (E)-Germacrene D & 2.54 & IK, MS \\
\hline 13.66 & -- Elemene & 1.02 & IK, MS \\
\hline 13.94 & --Cadinene & 0.12 & $\mathrm{IK}, \mathrm{MS}$ \\
\hline 14.66 & Gamma himachalene & 0.38 & $\mathrm{IK}, \mathrm{MS}$ \\
\hline \multirow[t]{2}{*}{14.74} & Unknown & 0.14 & IK, MS \\
\hline & Total & 100 & \\
\hline
\end{tabular}

${ }^{*}$ Compounds were identified comparing with mass spectral database (MS) and based on the Kovats retention indices (IK) and pure standards (S).

The season of field-collection of leaves and the geographical area of trees may account for the differences in the chemical composition of the essential oil. The material used in this study was collected in the area of Maullín, Los Lagos Region, while the other studies used material field-collected in La Araucanía Region (Toledo et al., 2014), Los Ríos Region (Niemeyer and Teillier, 2007), and Biobío Region (Bittner et al., 2009). Tepa leaves used in these bioassays were collected during summer time, which coincides with the study conducted by Toledo et al. (2014) and Niemeyer and Teillier (2007), but it differs with Bittner et al. (2009), who field-collected material on fall. Hussain et al. (2010) indicated that the composition of essential oils may vary depending on the latitude and season, plant age, as well as drying and extraction methods used.

Essential oils components and proportions may also vary according to climate, soil composition, plant part, age and physiological stage of the plant's reproductive cycle (Angioni et al., 2006). However, despite these possible variations, tepa essential oil showed toxicity to insects in the studies conducted by Bittner et al. (2009) and Toledo et al. (2014). Therefore, it can be inferred that tepa essential oil presents insecticidal potential against insect pests.

\section{Contact and fumigant toxicity}

The highest toxicity level after 15 DAI in the three species of Sitophilus was observed with oil at the concentration of $4.0 \%$, with the highest level being recorded in S. oryzae with $94 \%$ mortality. In S. zeamais and S. granarius, oil at the same concentration reached $60.15 \%$ and $67.10 \%$ dead insects, respectively. The three Sitophilus species vary in their level of susceptibility to L. philippiana essential oil, ranging from 
high to low: S. oryzae $>$ S. zeamais $>$ S. granarius (Table 2). Treatments at concentrations below $4.0 \%$ showed $30 \%$ and $40 \%$ mortality in $S$. zeamais and $S$. granarius, respectively. In $S$. oryzae, mortality reached $50 \%$ and $70 \%$ with essential oil at concentrations of $1.0 \%$ to $2.0 \%$. Similar results were documented by Ortiz et al. (2012), who found that the powder of L. philippiana at concentrations higher than $0.25 \%$ resulted in more than $60 \%$ mortality of Tribolium castaneum. Sitophilus oryzae is the most susceptible species to tepa essential oil and treatments with concentrations above $2.0 \%$ are promising.

Contact toxicity could be attributed to the activity of both safrole and methyleugenol. Zapata and Smagghe (2010) documented toxicity of the essential oil obtained from the bark of L. sempervirens against $S$. zeamais, also identified safrole $(49.71 \%)$ and methyleugenol $(18.04 \%)$ as the main components. Other studies on essential oils with high concentrations of safrole, such as essential oil of Piper hispidinervum C. DC. (82\%), have reported insecticidal activity against larvae of Spodoptera frugiperda J.E. Smith (Lepidoptera, Noctuidae) (Lima et al., 2009). Regarding methyleugenol, Islam et al. (2010) reported contact toxicity against $S$. oryzae and Callosobruchus maculatus (F.) (Coleoptera: Bruchidae), while Coitinho et al. (2006) documented toxicity of $100 \%$ and a lethal time $50 \%\left(\mathrm{LT}_{50}\right)$ of $4.6 \mathrm{~d}$ using eugenol against $S$. zeamais.

In terms of adult emergence $\left(\mathrm{F}_{1}\right)$, as the concentration of essential oil increases, the percentage of emergence decreases (Table 2). In $S$. oryzae and $S$. granarius, $\mathrm{F}_{1}$ was reduced by $60 \%$ with essential oil at the concentration $4.0 \%$, while reduction did not exceed $50 \%$ in case of $S$. zeamais. The results indicate that tepa essential oil has an insectistatic effect, and causes alterations in its reproductive stage, possibly due to ovicidal or oviposition deterrent effects.

Table 2. Contact toxicity and effect of Laureliopsis philippiana essential oil on the emergence $\left(F_{1}\right)$ of Sitophilus zeamais, $S$. oryzae, and $S$. granarius under laboratory conditions.

\begin{tabular}{lccc}
\hline Species & $\begin{array}{c}\text { Concentration } \\
(\mathrm{v} / \mathrm{v})\end{array}$ & Mortality $\pm \mathrm{SD}$ & Emergence \pm SD \\
\cline { 2 - 3 } S. zeamais & 0.25 & $10.2 \pm 2.9 \mathrm{a}$ & $87.7 \pm 14.6 \mathrm{a}$ \\
& 0.50 & $21.7 \pm 4.9 \mathrm{ab}$ & $77.5 \pm 11.7 \mathrm{a}$ \\
& 1.00 & $24.3 \pm 4.9 \mathrm{ab}$ & $71.0 \pm 21.2 \mathrm{a}$ \\
& 2.00 & $29.4 \pm 11.3 \mathrm{~b}$ & $68.3 \pm 20.8 \mathrm{a}$ \\
& 4.00 & $60.2 \pm 11.3 \mathrm{c}$ & $64.1 \pm 10.3 \mathrm{a}$ \\
\hline CV, \% & & 15.7 & 22.1 \\
\hline S. oryzae & 0.25 & $24.6 \pm 5.1 \mathrm{a}$ & $80.8 \pm 19.1 \mathrm{~b}$ \\
& 0.50 & $38.9 \pm 10.7 \mathrm{a}$ & $78.8 \pm 17.0 \mathrm{~b}$ \\
& 1.00 & $50.6 \pm 6.7 \mathrm{ab}$ & $58.8 \pm 10.1 \mathrm{ab}$ \\
& 2.00 & $70.1 \pm 17.6 \mathrm{~b}$ & $46.9 \pm 8.8 \mathrm{a}$ \\
CV, \% & 4.00 & $94.8 \pm 5.9 \mathrm{c}$ & $42.7 \pm 13.0 \mathrm{a}$ \\
\hline S. granarius & & 16.6 & 23.1 \\
& 0.25 & $26.31 \pm 12.8 \mathrm{a}$ & $83.2 \pm 14.0 \mathrm{c}$ \\
& 0.50 & $28.94 \pm 9.1 \mathrm{a}$ & $70.4 \pm 14.4 \mathrm{c}$ \\
& 1.00 & $34.21 \pm 10.9 \mathrm{a}$ & $65.3 \pm 10.0 \mathrm{bc}$ \\
& 2.00 & $35.52 \pm 2.6 \mathrm{a}$ & $44.1 \pm 3.6 \mathrm{ab}$ \\
CV, \% & 4.00 & $67.10 \pm 6.6 \mathrm{~b}$ & $38.3 \pm 11.2 \mathrm{a}$ \\
\hline
\end{tabular}

Treatments with the same letter in the same species do not differ significantly according to Tukey's test $(\alpha \leq 0.05)$.

SD: Standard deviation, CV: coefficient of variation.
Ortiz et al. (2012) have indicated that the reduction of $F_{1}$ is directly related to the contact toxicity because it decreases the population of insects that can reproduce and it also interferes with insect mating habits.

The residual effect of contact toxicity of essential oil of L. philippiana did not surpass, in all Sitophilus species, $7 \%$ mortality including the treatment of $1 \mathrm{~d}$ storage (Table 3 ). These results show that residuality of essential oil of $L$. philippiana is very limited which is one of more frequent problems of botanical pesticides.

In the fumigant effect, concentrations of 200 and 240 $\mu \mathrm{L}$ oil $\mathrm{L}^{-1}$ air reached $100 \%$ mortality in the three species of Sitophilus. However, these treatments did not show significant differences with concentrations equal or above $140 \mu \mathrm{L}$ oil air $\mathrm{L}^{-1}$ (Table 4 ). The treatments of 35 and 70

Table 3. Residuality under laboratory conditions of contact toxicity of essential oil of Laureliopsis philippiana against Sitophilus zeamais, $S$. oryzae, and $S$. granarius.

\begin{tabular}{lcccc} 
& \multicolumn{4}{c}{ Mortality $\pm \mathrm{SD}$} \\
\cline { 2 - 5 } Insect & $\begin{array}{c}\text { Concentration } \\
(\mathrm{v} / \mathrm{v})\end{array}$ & $1 \mathrm{~d}^{*}$ & $5 \mathrm{~d}^{*}$ & $10 \mathrm{~d}^{*}$ \\
\cline { 2 - 5 } & & & & \\
S. zeamais & 2.0 & $3.8 \pm 0.0 \mathrm{a}$ & $2.5 \pm 2.5 \mathrm{a}$ & $2.5 \pm 2.5 \mathrm{a}$ \\
& 4.0 & $5.1 \pm 2.5 \mathrm{a}$ & $3.8 \pm 2.5 \mathrm{a}$ & $3.8 \pm 2.5 \mathrm{a}$ \\
\hline S. oryzae & 2.0 & $5.0 \pm 0.0 \mathrm{a}$ & $2.5 \pm 2.5 \mathrm{a}$ & $2.5 \pm 2.5 \mathrm{a}$ \\
& 4.0 & $6.3 \pm 2.5 \mathrm{a}$ & $2.5 \pm 2.5 \mathrm{a}$ & $2.5 \pm 2.5 \mathrm{a}$ \\
\hline S. granarius & 2.0 & $2.5 \pm 2.5 \mathrm{a}$ & $2.5 \pm 2.5 \mathrm{a}$ & $0.0 \pm 0.0 \mathrm{a}$ \\
& 4.0 & $2.5 \pm 2.5 \mathrm{a}$ & $2.5 \pm 2.5 \mathrm{a}$ & $2.5 \pm 2.5 \mathrm{a}$ \\
\hline
\end{tabular}

*Treatments with the same letter in the same species do not differ significantly according to Kruskal Wallis no parametric test $(\alpha \leq 0.05)$.

SD: Standard deviation.

Table 4. Fumigant toxicity of Laureliopsis philippiana essential oil against Sitophilus zeamais, $S$. oryzae, and $S$. granarius under laboratory conditions.

\begin{tabular}{lcc}
\hline Species & Concentration & Mortality $\pm \mathrm{SD}$ \\
\hline S. zeamais & $\mu$ L essential oil $\mathrm{L}^{-1}$ air & $\%$ \\
& 35 & $2.5 \pm 5.0 \mathrm{a}$ \\
& 70 & $20.0 \pm 8.1 \mathrm{ab}$ \\
& 100 & $50.0 \pm 21.6 \mathrm{a}$ \\
& 140 & $82.5 \pm 17.0 \mathrm{c}$ \\
& 170 & $90.0 \pm 8.1 \mathrm{c}$ \\
& 200 & $100.0 \pm 0.0 \mathrm{c}$ \\
CV, \% & 240 & $100.0 \pm 0.0 \mathrm{c}$ \\
\hline S. oryzae & & 17.1 \\
& 35 & $5.0 \pm 5.7 \mathrm{a}$ \\
& 70 & $20.0 \pm 14.1 \mathrm{a}$ \\
& 100 & $27.5 \pm 28.7 \mathrm{a}$ \\
& 140 & $72.5 \pm 29.8 \mathrm{~b}$ \\
& 170 & $85.0 \pm 17.3 \mathrm{~b}$ \\
CV, \% & 200 & $100.0 \pm 0.0 \mathrm{~b}$ \\
S. granarius & 240 & $100.0 \pm 0.0 \mathrm{~b}$ \\
& & 30.6 \\
& 35 & $10.0 \pm 8.1 \mathrm{a}$ \\
& 70 & $17.5 \pm 17.0 \mathrm{a}$ \\
& 100 & $75.0 \pm 10.0 \mathrm{~b}$ \\
& 140 & $95.0 \pm 5.7 \mathrm{c}$ \\
CV, \% & 170 & $97.5 \pm 5.0 \mathrm{c}$ \\
Treat & 200 & $100.0 \pm 0.0 \mathrm{c}$ \\
& 240 & $100.0 \pm 0.0 \mathrm{c}$ \\
\hline & & 12.1
\end{tabular}

Treatments with the same letter in each species do not differ significantly according to Tukey's test $(\alpha \leq 0.05)$.

SD: Standard deviation, CV: coefficient of variation. 
$\mu \mathrm{L}$ oil $\mathrm{L}^{-1}$ air did not exceed $20 \%$ dead insects. Sitophilus granarius was the most susceptible species because the concentration of $100 \mu \mathrm{L}$ oil L $^{-1}$ air resulted in $70 \%$ mortality. On the contrary, S. oryzae was the least susceptible species with $27.5 \%$ mortality at the same concentration. Same as in contact toxicity, mortality increases in the three species of Sitophilus as oil concentration increases.

Inhalation toxicity of L. philippiana essential oil could be attributed to safrole and methyleugenol activity. Other studies with essential oils, identified them as the main compounds and obtained similar results. Kim and Park (2008) and Chu et al. (2011) demonstrated that safrole by itself can act as a fumigant against $S$. oryzae, $S$. zeamais and T. castaneum. Zapata and Smagghe (2010) reported fumigant toxicity of essential oil from leaves and bark of $L$. sempervirens against $T$. castaneum, which is other species of the Atherospermataceae family that has these compounds. Moreover, in a study with essential oil of Piper uduncum L., species which also contains high level of safrole, caused $100 \%$ mortality of adult S. zeamais (Estrela et al., 2006). Therefore, these results show that L. philippiana oil exert fumigant effects against insects of stored grains.

\section{Repellent and antifeedant effects}

All of the treatments evaluated in this study showed repellent effect against all species of Sitophilus. Values obtained for the repellency index $(\mathrm{RI})$ were lower than 1 , which according to Restello et al. (2009) is considered as a repellent (Table 5). In the case of $S$.zeamais, RI values observed with the essential oil at concentrations of $0.25 \%$ and $0.5 \%$ were 0.84 and 0.86 .

Table 5. Repellent and antifeedant effect of $L$. philippiana essential oil against adults of Sitophilus zeamais, $S$. oryzae, and S. granarius under laboratory conditions.

\begin{tabular}{lccc}
\hline Species & $\begin{array}{c}\text { Concentration } \\
(\mathrm{v} / \mathrm{v})\end{array}$ & $\begin{array}{c}\text { Repellency index } \\
(\mathrm{RI})^{1} \pm \mathrm{SD}\end{array}$ & $\begin{array}{c}\text { Antifeedant index } \\
(\mathrm{AI})^{*} \pm \mathrm{SD}\end{array}$ \\
\hline S. zeamais & $\%$ & $0.8 \pm 0.1(\mathrm{R})$ & $33.8 \pm 35.7 \mathrm{a}$ \\
& 0.25 & $0.9 \pm 0.2(\mathrm{R})$ & $34.3 \pm 21.1 \mathrm{a}$ \\
& 0.50 & $0.7 \pm 0.1(\mathrm{R})$ & $37.5 \pm 40.3 \mathrm{a}$ \\
& 1.00 & $0.3 \pm 0.3(\mathrm{R})$ & $38.2 \pm 29.3 \mathrm{a}$ \\
& 2.00 & $0.2 \pm 0.2(\mathrm{R})$ & $38.8 \pm 40.6 \mathrm{a}$ \\
\hline CV, \% & 4.00 & & 65.14 \\
\hline S. oryzae & 0.25 & $0.6 \pm 0.1(\mathrm{R})$ & $30.1 \pm 18.4 \mathrm{a}$ \\
& 0.50 & $0.6 \pm 0.1(\mathrm{R})$ & $60.2 \pm 18.2 \mathrm{ab}$ \\
& 1.00 & $0.4 \pm 0.2(\mathrm{R})$ & $78.7 \pm 5.3 \mathrm{~b}$ \\
& 2.00 & $0.6 \pm 0.1(\mathrm{R})$ & $82.3 \pm 16.3 \mathrm{~b}$ \\
CV, \% & 4.00 & $0.4 \pm 0.1(\mathrm{R})$ & $82.9 \pm 15.1 \mathrm{~b}$ \\
\hline S. granarius & 0.25 & & 23.12 \\
& 0.50 & $0.6 \pm 0.1(\mathrm{R})$ & $39.4 \pm 12.0 \mathrm{a}$ \\
& 1.00 & $0.6 \pm 0.2(\mathrm{R})$ & $39.6 \pm 37.0 \mathrm{a}$ \\
& 2.00 & $0.7 \pm 0.3(\mathrm{R})$ & $42.1 \pm 32.0 \mathrm{a}$ \\
& 4.00 & $0.7 \pm 0.1(\mathrm{R})$ & $42.4 \pm 27.3 \mathrm{a}$ \\
CV, \% & & $0.5 \pm 0.1(\mathrm{R})$ & $47.4 \pm 12.6 \mathrm{a}$ \\
\hline
\end{tabular}

${ }^{1}$ Repellence Index (RI) was not subjected to statistical analysis because treatments were categorized by the next scale according to Restello et al. (2009): RI > 1 Attracting (A), RI = 1 Neutral (N), RI < 1 Repellent (R). Hence a coefficient of variation is not indicated.

SD: Standard deviation, CV: coefficient of variation.

*Treatments with the same letter in each species do not differ significantly according to Tukey $(\alpha \leq 0.05)$.
Moreover, $2.0 \%$ and $4.0 \%$ doses presented an index value closer to zero $(0.27$ and 0.21$)$, which indicates that higher concentrations have a higher repellent effect. With respect to $S$. granarius and $S$. oryzae, RI values obtained with the different concentration evaluated ranged between 0.5 and 0.79 .

The repellent effect obtained can be attributed to the high content of safrole since studies on the essential oil of Piper auritum Kunth, which has $93.2 \%$ of this compound, also showed repellency against T. castaneum (Caballero-Gallardo et al., 2014). Ogendo et al. (2008) classified safrole as the most effective insect repellent among several compounds isolated from essential oils. Salgado et al. (2012) indicated that the repellent activity is a key factor when selecting an essential oil for the control of stored grain pests since the greater this effect, the lower insect infestation, resulting in a reduction or suppression of oviposition and $\mathrm{F}_{1}$ of emerged insects.

The antifeedant effect (AE) did not exceed $50 \%$ in $S$. zeamais and $S$. granarius, with nonsignificant differences between the different concentrations of essential oil (Table $5)$. In the case of $S$. oryzae, as the concentration increased, the antifeedant effect of the essential oil also increased which, unlike the other two species, exceeded $80 \%$ with $2.0 \%$ and $4.0 \%$ doses. Nonsignificant differences were found between concentrations higher than $0.25 \%$. The reduction in food intake by the evaluated species may be due to the presence of methyleugenol in the essential oil. Saroukolai et al. (2014) assessed the essential oil of Eugenia caryophyllus (Segel) Bullock \& S.G. Hanson (Myrtaceae) (68.4\% eugenol) against Leptinotarsa decemlineata Say (Coleoptera: Chrysomelidae) obtained a feeding deterrence index of $33.9 \%$. Furthermore according to Tan and Nishida (2012) methyl eugenol present in the growing bud of Artemisia spp. exhibited $100 \%$ antifeeding activity against larvae of Pieris rapae crucivora (Lepidoptera: Pieridae). However, many authors have highlighted the importance of determining the effects of these derivatives of benzene on insect nutrition in order to explore the potential of their properties for pest control and management (Ogendo et al., 2008; Kim and Park, 2008; Islam et al., 2010; Chu et al., 2011).

\section{Germination and plant development}

The essential oil of L. philippiana at concentrations below $2.0 \%$ did not affect maize kernel germination significantly (Table 6), ranging between $91.25 \%$ and $98.7 \%$. Germination reached $62.5 \%$ in the treatment of oil at a concentration of $4.0 \%$, value that was significantly lower compared to the rest of the treatments. Values obtained with oil at concentrations below $2.0 \%$ coincide with those obtained by Ortiz et al. (2012), who reported more than 90\% maize kernel germination with leaf powder of L. philippiana. In addition, a study that included trials with leaf powder of $P$. boldus (another species of the family Atherospermataceae) showed nonsignificant differences between treatments at $1.0 \%$ and $2.0 \%$ (93.4\% and $97.3 \%$ ) compared to the control $(100 \%)$ (Pizarro et al., 2014). The essential oil of L. philippiana did not caused phytotoxicity effects (Table 6). The plant height, DM weight and root length did not exhibited significant 
Table 6. Effect of Laureliopsis philippiana essential oil on the germination and development of maize kernels treated with different concentrations.

\begin{tabular}{|c|c|c|c|c|c|}
\hline $\begin{array}{l}\text { Concentration } \\
(\mathrm{v} / \mathrm{v})(\%)\end{array}$ & $\begin{array}{c}\text { Germination }^{1 *} \\
\pm \mathrm{SD}\end{array}$ & $\begin{array}{c}\text { Plant } \\
\text { height }^{1} \pm \text { SD }\end{array}$ & $\begin{array}{l}\text { Fresh matter } \\
\text { weight }^{1} \pm \text { SD }\end{array}$ & $\begin{array}{c}\mathrm{DM} \\
\text { weight }^{1} \pm \mathrm{SD}\end{array}$ & $\begin{array}{c}\text { Root } \\
\text { length }^{1} \pm S D\end{array}$ \\
\hline & $\%$ & $\mathrm{~cm}$ & $\%$ & & \\
\hline Control & $100 \pm 0.0 c$ & $19.8 \pm 5.5 \mathrm{a}$ & $0.8 \pm 0.4 a$ & $0.2 \pm 0.1 \mathrm{a}$ & $13.3 \pm 10.2 \mathrm{a}$ \\
\hline 0.25 & $98.8 \pm 2.5 b c$ & $25.3 \pm 4.4 a$ & $1.5 \pm 0.5 \mathrm{ab}$ & $0.3 \pm 0.1 \mathrm{a}$ & $21.1 \pm 8.5 \mathrm{a}$ \\
\hline 0.50 & $98.8 \pm 2.5 b c$ & $22.0 \pm 4.6 \mathrm{a}$ & $1.4 \pm 0.5 \mathrm{ab}$ & $0.4 \pm 0.1 \mathrm{a}$ & $16.6 \pm 7.5 a$ \\
\hline 1.00 & $91.3 \pm 4.8 b$ & $24.1 \pm 4.9 \mathrm{a}$ & $1.4 \pm 0.5 \mathrm{ab}$ & $0.4 \pm 0.1 \mathrm{a}$ & $17.4 \pm 10.9$ \\
\hline 2.00 & $91.3 \pm 2.5 b$ & $24.4 \pm 5.9 a$ & $1.3 \pm 0.6 \mathrm{ab}$ & $0.3 \pm 0.1 \mathrm{a}$ & $19.4 \pm 9.3 \mathrm{a}$ \\
\hline 4.00 & $62.5 \pm 16.6 a$ & $22.5 \pm 5.2 \mathrm{a}$ & $2.1 \pm 0.9 b$ & $0.4 \pm 0.1 \mathrm{a}$ & $18.6 \pm 8.8 \mathrm{a}$ \\
\hline $\mathrm{CV}, \%$ & 7.8 & 12.6 & 20.6 & 16.5 & 12.6 \\
\hline
\end{tabular}

*Germination of the control treatment was considered as $100 \%$.

${ }^{1}$ Treatments with the same letter do not differ significantly according to Tukey's text $(\alpha \leq 0.05)$.

SD: Standard deviation; CV: coefficient of variation.

differences $(\mathrm{p}>0.05)$ in comparison with the untreated control.

The essential oil of L. philippiana at concentrations below $2.0 \%$ does not show phytotoxic effects. Therefore, tepa essential oil at these concentrations can be used as a kernel protection since the Servicio Agrícola y Ganadero (SAG) (SAG, 2000) from Chilean government requires $90 \%$ germination to be sold as seed.

\section{CONCLUSIONS}

The essential oil from leaves of Laureliopsis philippiana exert contact and fumigant toxicity, as well as repellent and antifeedant activity against adults of Sitophilus zeamais, $S$. oryzae and S. granarius. Oil concentrations below $4 \%(\mathrm{v} / \mathrm{v})$ do not affect germination of maize kernels significantly.

\section{ACKNOWLEDGEMENTS}

This study was funded by Comisión Nacional de Investigación Científica y Tecnológica (CONICYT) throughout Fondo Nacional de Desarrollo Científico y Tecnológico (FONDECYT) Initiation Program Project nr 11110105 .

\section{REFERENCES}

Abbott, W.S. 1925. A method of computing the effectiveness of an insecticide. Journal of Economic Entomology 18:265-267.

Angioni, A., A. Barra, V. Coroneo, S. Dessi, and P. Cabras. 2006. Chemical composition, seasonal variability, and antifungal activity of Lavandula stoechas L. ssp. stoechas essential oils from stem/leaves and flowers. Journal of Agricultural Food Chemistry 54:4364-4370.

Bakkali, F., S. Averbeck, D. Averbeck, and M. Idaomar. 2008. Biological effects of essential oils - A review. Food Chemistry Toxicology 46:446-475.

Betancur, J., G. Silva, J.C. Rodríguez, S. Fischer, and N. Zapata. 2010. Insecticidal activity of Peumus boldus Molina essential oil against Sitophilus zeamais Motschulsky. Chilean Journal of Agricultural Research 70:399-407.
Bittner, M., M. Aguilera, V. Hernández, C. Arbert, J. Becerra, and M. Casanueva. 2009. Fungistatic activity of essential oils extracted from Peumus boldus Mol., Laureliopsis philippiana (Looser) Schodde and Laurelia sempervirens (Ruiz \& Pav.) Tul. (Chilean Atherospermataceae). Chilean Journal of Agricultural Research 69:30-37.

Brito, J., J. Oliveira, e S. De Bortoli. 2006. Toxicidade de óleos essenciais de Eucalyptus spp. sobre Callosobruchus maculatus (Fabr. 1775) (Coleoptera: Bruchidae). Revista Biología e Ciências da Terra 6:96-103.

Caballero-Gallardo, K., J. Verbel, N. Benítez, and E. Stashenko. 2014. Chemical composition and bioactivity of Piper auritum and P. multiplinervium essential oils against the red flour beetle, Tribolium castaneum (Herbst). Boletín Latinoamericano y del Caribe de Plantas Medicinales y Aromáticas 13:10-19.

Chu, S.S., Q.R. Liu, and Z.L. Liu. 2010. Insecticidal activity and chemical composition of the essential oil of Artemisia vestita from China against Sitophilus zeamais. Biochemical Systematics and Ecology 38:489-492.

Chu, S.S., C.F. Wang, S.S. Du, S.L. Liu, and Z.L. Liu. 2011. Toxicity of the essential oil of Illicium difengpi stem bark and its constituent compounds towards two grain storage insects. Journal of Insect Science 11:1-10.

Coitinho, R., J. de Oliveira, M. Gondim, e C. da Camara. 2006. Toxicidade por fumigacao, contacto e ingestao de oleos essenciais para Sitophilus zeamais Motschulsky 1885 (Coleoptera: Curculionidae). Ciencia e Agrotecnologia. 35:172-178.

De Lira, C., E.V. Pontual, L.P. De Albuquerque, L.M. Paiva, P.G. Paiva, J.V. De Oliveira, et al. 2015. Evaluation of the toxicity of essential oil from Alpinia purpurata inflorescences to Sitophilus zeamais (maize weevil). Crop Protection 71:95-100.

Estrela, J., M. Fazolin, V. Catani, M. Alécio, e M. Santos de Lima. 2006. Toxicidade de óleos essenciais de Piper aduncum e Piper hispidinervum em Sitophilus zeamais. Pesquisa Agropecuaria Brasileira 41:217-222.

Halstead, D. 1963. External sex differences in stored-products Coleoptera. Bulletin of Entomological Research 54:119-134.

Haouas, D., G. Flamini, M. Halima-Kamel, and M.H. Hamouda. 2010. Feeding perturbation and toxic activity of five Chrysantemum species crude extracts against Spodoptera littoralis (Boisduval) (Lepidoptera; noctuidae). Crop Protection 29:992-997.

Hussain, A.I., F. Anwar, P. S. Nigam, M. Ashraf, and A. H. Gilani. 2010. Seasonal variation in content, chemical composition and antimicrobial and cytotoxic activities of essential oils from four Mentha species. Journal of the Science of Food and Agriculture 90:1827-1836. 
Islam, M.S., M.M. Hasan, C. Lei, T. Mucha-Pelzer, I. Mewis, and C. Ulrichs. 2010. Direct and mixture toxicity of diatomaceous earth and monoterpenoids against the storage pests Callosobruchus maculatus (F.) and Sitophilus oryzae (L.) Journal of Pest Science $83: 105-112$

Isman, M.B. 2006. Botanical insecticides, deterrents, and repellents in modern agriculture and an increasingly regulated world. Annual Review of Entomology 51:45-66.

Isman, M.B. 2008. Perspective botanical insecticides: for richer, for poorer. Pest Management Science 64:8-11.

Kim, J., and I. Park. 2008. Fumigant toxicity of Korean medicinal plant essential oils and components from Asiasarum sieboldi root against Sitophilus oryzae L. Flavour and Fragance Journal 23:79-83.

Lima, R., M. Cardoso, J. Moraes, B. Melo, V. Rodrigues, e P. Guimarães. 2009. Atividade insecticida do óleo essencial de pimenta longa (Piper hispidinervum C. DC.) sobre lagarta-docartucho do milho Spodoptera frugiperda (J.E. Smith, 1797) (Lepidoptera: Noctuidae). Acta Amazonica 39:377-382.

Napoleao, T.H., B. Belmonte, E. Pontual, L. Albuquerque, R. Sa, L. Paiva, et al. 2013. Deleterious effects of Myracrodruon urundeuva leaf extract and lectin on the maize weevil, Sitophilus zeamais (Coleoptera, Curculionidae). Journal of Stored Product Research 54:26-33.

Niemeyer, H., y S. Teillier. 2007. Aromas de la flora nativa de Chile. Universidad de Chile, Santiago, Chile.

Ogendo, J.O., M. Kostyukovsky, U. Ravid, J.C. Matasyoh, A.L. Deng, E.O. Omolo, et al. 2008. Bioactivity of Ocimum gratissimum L. oil and two of its constituents against five insect pests attacking stored food products. Journal of Stored Product Research 44:328-334.

Ortiz, A., G. Silva, A. Urbina, N. Zapata, J. Rodriguez, and A. Lagunes. 2012. Bioactivity of tepa (Laureliopsis Philippiana (Looser) Shodde) power to Sitophilus zeamais Motschulsky control in laboratory. Chilean Journal of Agricultural Research 72:68-73.

Pérez, J.C., O. Pino, S. Ramírez, y M. Suris. 2012. Evaluación de productos naturales para el control de Lasioderma serricorne (F.) (Coleoptera: Anobiidae) sobre garbanzo (Cicer arietinum L.) en condiciones de laboratorio. Revista de Protección Vegetal 27:26-32.

Pérez, S., M.A. Ramos, M.A. Zavala, and N.C. Cardenas. 2010. Activity of essential oils as a biorational alternative to control coleopteran insects in stored grains. Journal of Medicinal Plants Research 4:2827-2835.
Pizarro, D., G. Silva, M. Tapia, J.C. Rodríguez, A. Urbina, I. Figueroa, et al. 2014. Aceite esencial de follaje de Peumus boldus Molina colectado en otoño para el control del gorgojo del maíz Sitophilus zeamais Motschulsky. Chilean Journal of Agricultural and Animal Science (ex Agro-Ciencia) 30:171-180.

Restello, R.M., C. Menegatt, e A.J. Mossi. 2009. Efeito do oleo essencial de Tagetes patula L. (Asteraceae) sobre Sitophilus zeamais Motschulsky (Coleoptera, Curculionidae). Revista Brasileira de Entomologia 53:304-307.

SAG. 2000. Normas generales y específicas de certificación de semillas. Ministerio de Agricultura de Chile, Servicio Agrícola y Ganadero (SAG), Departamento de Semillas, Santiago, Chile. Available at http://www.sag.gob.cl/sites/default/files/NORMAS_ GENERALES_SEMILLAS.pdf (accessed December 2015).

Salgado, N., L. Faroni, y A. Soto. 2012. Aceite esencial de Piper crassinervum para el control de Sitophilus zeamais (Coleoptera: Curculionidae). Boletín Científico del Museo de Historia Natural 16:99-107.

Saroukolai, A., G. Nouri-Ganbalani, H. Rafiee-Dastjerdi, and J. Hadian. 2014. Antifeedant activity and toxicity of some plant essential oils to Colorado potato beetle, Leptinotarsa decemlineata Say (Coleoptera: Chrysomelidae). Plant Protection Science 50:207-216.

Tan, K., and R. Nishida. 2012. Methyl eugenol: Its occurrence, distribution, and role in nature, especially in relation to insect behavior and pollination. Journal of Insect Science 12:1-74.

Tefera, T., S. Mugo, and P. Likhayo. 2011. Effects of insect population density and storage time on grain damage weight loss in maize due to the maize weevil Sitophilus zeamais and the larger grain borer Prostephanus truncatus. African Journal of Agricultural Research 6:2249-2254.

Toledo, D., A. Mutis, E. Hormazabal, R. Palma, M. Parada, E. Scheuermann, et al. 2014. Chemical composition and antibacterial activity of Laureliopsis philippiana (Looser) essential oil. Boletín Latinoamericano y del Caribe de Plantas Medicinales y Aromáticas 13:117-125.

Zapata, N., and G. Smagghe. 2010. Repellency and toxicity of essential oils from the leaves and bark of Laurelia sempervirens and Drimys winteri against Tribolium castaneum. Industrial Crops and Products 32:405-410. 